influence the severity of the toxic effect and it seems difficult to define damaging pasture concentrations, but a tolerance-level of between 30 and 50 p.p.m. in the food was given.

Mr. R. H. Burns (Atomic Energy Research Establishment), the first speaker in the final session, devoted to pollution by radioactive wastes, outlined the main differences between radioactive and other waste materials, the most important being our inability to destroy the harmful properties of the former by chemical means. Methods of dealing with wastes, disposal and storage, were described. There is an increasing demand for some of the fission products, particularly radiocæsium and radiostrontium, in industry and medicine, and storage of liquid wastes, though expensive, costing $£ 200$ per cubic metre, is being used on an increasing scale. Mr. Burns demonstrated by his paper how carefully such factors as the proper siting of effluent pipes and the fixing of permissible levels of discharge are considered in relation to the disposal of radioactive wastes.

Mr. W. L. Templeton (U.K. Atomic Energy Authority) directed attention to the greater hazards that may arise from accumulation of radioactive isotopes from the diluting medium by food-organisms than by direct radiation from the environment. The value of the observational and experimental approaches in the measurement of accumulation factors was outlined and their findings surveyed. Mr. Templeton felt, however, that series of planned experimental discharges, each of several months duration, would be of the greatest value in determining long-term variations and build-up of activity.
Dr. H. J. M. Bowen (Wantage Radiation Laboratory), discussing the uptake of fission products by plants, outlined recent advances in our knowledge of their absorption by various plant structures and their translocation in plant tissues. Dr. Bowen described his work with accumulator plants, that is, plants which concentrate large quantities of specific elements. He found that radiostrontium, the most dangerous fission product, was accumulated particularly by certain species of Fucus and Laminaria. It would seem that one important gap in our knowledge is that of the relation of rainfall and soil-type to the accumulation of fission products by plants.

In the last paper of the symposium, entitled "Genetic Hazards of Radioactive Pollution", Dr. T. C. Carter (Medical Research Council) suggested that recent work casts doubt on assumptions made by experimental geneticists, based principally on the radiation effects on gene mutation in Drosophila sperms. It is on these questionable assumptions that radiation effects are calculated. Dr. Carter stressed the noed for an investigation of the relation between rates of mutation and accumulated radiation doses in mammals, particularly in the low-dosage range relevant to man. All present-day assessments of genetic hazards of radiation assume a linear relation. A figure of about $£ 200,000$ was quoted as the total outlay necessary for such an investigation. This is surely a small price to pay for such basic and vital information, especially when man's future well-being is at stake.

R. W. EDWards

1 Gorham, E., Trans. Roy. Soc., B, 241, 147 (1958).

${ }^{2}$ Allan, I. R. H., Herbert, D. W. M., and Alabaster, J. S., Fish Invest., $\boldsymbol{B}$, No. 2 (1958)

\title{
THE UNIVERSITY GRANTS COMMITTEE
}

\section{RETURNS FOR 1956-57}

T HE annual returns from universities and university colleges in receipt of Treasury grants for the academic year 1956--57, published by the University Grants Committee*, records a further increase of 4,672 in the number of full-time students, which now stands at 89,866 , compared with 81,705 in $1954-55$, and it is expected that the number in 1957-58 will show a greater increase since the number of fulltime students in the autumn term of 1957 was 5,899 greater than in the autumn term of 1955. There were 6,115 full-time and 2,016 part-time students from overseas within the British Commonwealth and 3,792 full-time and 1,756 part-time students from foreign countries; for 1955-56 the corresponding figures were 5,536 and 2,068 for the Commonwealth and 3,750 and 1,756 for foreign countries. Distribution of full-time students among the faculties showed no significant change, but the proportion in pure science increased from $21 \cdot 3$ to $22 \cdot 2$ per cent, in technology from $13 \cdot 3$ to 13.9 per cent, and that in medicine decreased from $15 \cdot 7$ to $14 \cdot 4$ per cent. Full-time advanced students of pure science numbered 3,675 (35 per cent); of technology 1,650 (15.7 per cent); and medicine and dentistry 1,041 (9.9 per cent) ; 2,870 students were working for the - University Grants Committee. Returns from Universities and University Colleges in receipt of Treasury Grant, Academic Year 1956-1957. Pp. 50. (Cmnd. 477.) (London: H.M. Stationery Office, 1958.) 4s. net. teacher's diploma. Of the full-time students, 71,713 were reading for a first degree, 3,969 for a first diploma, and 13,379 engaged in research or other advanced work, the corresponding figures for $1955-56$ being $67,850,4,021$ and 12,668 .

The proportion of assisted students was $75 \cdot 7$ per cent compared with 74.9 per cent in 1955-56 and 71.9 per cent in 1953-54, ranging from 90.4 per cent in Wales, 83.8 per cent for English universities and university colleges, excluding Oxford, Cambridge and London, to 61.7 per cent for Scotland. Of the recurrent income of $£ 41,635,609$ (an increase of $£ 3,338,958$ on $1955-56)$, $£ 29,082,526$ was from parliamentary grants $(69.8$ per cent). Income from fees decreased from $11 \cdot 2$ to 10.8 per cent, local authority grants increased from 2.9 to 3.1 per cent, payments for research from $6 \cdot 0$ to 6.5 per cent, gifts and sub. scriptions from 1.0 to 1.2 per cent, and endowments were again 4.0 per cent. Full-time teaching staff increased to 10,485 , compared with 10,202 in $1955-56$ and 9,810 in $1954-55$.

The proportion of full-time students residing in colleges and halls of residence was 27.4 per cent, compared with 27.5 in $1955-56$, but the total, 24,652, was higher. The proportion of men in residence was 23.2 per cent and of women 39.9 per cent ; whereas $41,291(46 \cdot 0$ per cent) were in lodgings and 23,923 $(26 \cdot 6$ per cent) at home, compared with $44 \cdot 7$ per cent 
and 27.8 per cent, respectively, in the previous year. Non-recurrent grants in respect of capital expenditure totalled $£ 9,134,185$, compared with $£ 7,084,366$ in 1955-56, and of the recurrent expenditure of $£ 41,509,703$-an increase of $9 \cdot 1$ per cent on $1955-56$ -7.0 per cent was spent on administration, 68.4 per cent on departmental maintenance, and 12.9 per cent on maintenance of premises. The largest increases were in rates, insurance, heat, light, water, wages, etc. (15.3 per cent), departmental wages (technicians and laboratory assistants) (14 per cent), and in repairs and maintenance of buildings (13.9 per cent). Expenditure on libraries (excluding general maintenance, rates, etc.) increased from $£ 1,468,512$ to $£ 1,620,958$ but remained at 3.9 per cent of the total.

\title{
SCIENTIFIC FILMS AT THE BRITISH ASSOCIATION
}

$\mathrm{F}^{\mathrm{o}}$ OR the fourth successive year the Scientific and Technical Group of the Royal Photographic Society of Great Britain, in conjunction with the Scientific Films Committee of the British Association, presented a series of research films as part of the annual meeting of the British Association. These films were shown in two sessions during the morning and afternoon of August 30. The morning session was under the chairmanship of Sir Raymond Priestley, and during the afternoon $\mathrm{Mr}$. Bowler, vice-president of the Society, took the chair.

Several films were devoted to biological subjects, from the study of the mating behaviour of marsupial frogs to the investigation of cancerous cells. The muscle structure of sea-anemones, courtship of Drosophila melanogaster, nematodes and Leishmania donovani were also objects of investigation. In what might be described as the industrial field many problems have been covered with ciné techniques, including the casting of steel, coke-oven performance, vehicle suspension systems, flooring research, bookbinding operations and the flow of water in large pipes.

From the psychological aspect, two films were shown which demonstrated techniques that have been employed to identify the particular point of a general scene at which a subject is looking, thus enabling eye co-ordination to be studied. Also in this field an extract was shown from a film which studied parent/child relationship in an experimental treatment of the problems involved in admission to hospital of children under school age.

In pure physics, the motion of electrons in electric fields was demonstrated by means of charged droplets ; this film was made in Germany. Automatic self-replication was also shown by ingenious systems of models. Finally, Mr. Hallett, secretary of the Society, gave a short talk on the scope and aims of the "Encyclopædia Cinematographica", with examples of research films loaned by Dr. Wolf, of Göttingen.

Among the methods used to prepare these films were time-lapse and high-speed ciné-photography, interference and phase-contrast microscopy, electron microscopy and television techniques. Colour and monochrome, silent and sound-track films were all represented at this meeting, which admirably demonstrated the wide variety of ways in which photography can be of use in research in an equally wide range of scientific investigation.

A more detailed report will be published in the Journal of Photographic Science.

\section{A STRUCTURAL THEORY FOR METAL ALKOXIDE POLYMERS}

\author{
By DR. D. C. BRADLEY
}

Department of Chemistry, Birkbeck College, University of London

$\mathrm{R}$ ECEN'T studies ${ }^{1,2}$ on the metal alkoxides $M(\mathrm{O} R)_{n}$, where $M$ is an $n$-valent metal and $R$ is an alkyl group, have established that derivatives with the lower primary or secondary alkyl groups are in fact polymeric, that is $\left\{M(\mathrm{O} R)_{n}\right\}_{x}$, where $x$ is the degree of polymerization. It is believed that this polymerization is caused by intermolecular bonds involving the metal and oxygen atoms, namely :

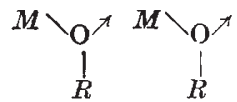

and is a manifestation of the tendency of the metal to expand its covalency by co-ordination with oxygen. It is a striking feature of the metal alkoxides that the alternative mechanism for this covalency expansion, namely, co-ordination between the alkoxide and a ligand containing oxygen or nitrogen (for example, $\left.M(\mathrm{O} R)_{n}, x L\right)$ is relatively rare and this suggests a special stability for the polymer. Moreover, it is a general rule that, in a series of metal alkoxides with metals of the same sub-group (for example, titanium, zirconium, thorium) and having the same alkyl groups, the degree of polymerization $x$ increases with the size of the metal atom. Nevertheless, only in a few cases have structures been suggested for metal alkoxide polymers ${ }^{3-7}$. Another interesting feature of these compounds is that the polymers are relatively small compared with typical organic polymers and silicones. Recent studies on the hydrolysis of titanium alkoxides ${ }^{8,9}$ showed that the titanium oxide alkoxides $\mathrm{TiO}_{h}(\mathrm{O} R), h$ formed were also low polymers, and this behaviour was explained in terms of a series of structural models in which titanium was 6 -co-ordinated by oxygen. Further consideration of these structures reveals that in each case the degree of polymerization is unique in being the lowest possible, and this led me to explore the possibility of rationalizing the polymeric nature of metal alkoxides in terms of the stereochemistry of the metal. It is the purpose of this article to show that a rationalization can indeed be achieved on the basis of the following single new major assumption. It is assumed that the metal alkoxide adopts the smallest possible structural unit consistent with all the metal atoms attaining a higher co-ordination number. Also the choice of structure is limited by the condition that the co-ordination number of oxygen does not exceed 